\title{
Degradation of Bisphenol A by Nano-sized Manganese Dioxide Synthesized Using Montmorillonite as Templates
}

\author{
Lin Fang ${ }^{\mathrm{a}}$, Ran Hong ${ }^{\mathrm{a}}$, Juan Gao ${ }^{\mathrm{b}}$, Cheng $\mathrm{Gu}^{\mathrm{a}}$ * \\ ${ }^{\text {a }}$ State Key Laboratory of Pollution Control and Resource Reuse, School of the \\ Environment, Nanjing University, Nanjing 210023, P. R. China \\ ${ }^{\mathrm{b}}$ Key Laboratory of Soil Environment and Pollution Remediation, Institute of Soil \\ Science, Chinese Academy of Sciences, Nanjing, Jiangsu 210008, P. R. China
}

*To whom correspondence should be addressed

Cheng Gu

Professor

School of the Environment

Nanjing University

Nanjing, Jiangsu, 210023

P. R. China

Phone/Fax: +86-25-89680636

E-mail: chenggu@nju.edu.cn 
Abstract: A new method was developed to synthesize nanoscale manganese dioxide $\left(\mathrm{MnO}_{2}\right)$ using natural montmorillonite as the template. When the exchangeable $\mathrm{Mn}^{2+}$ cations reacted with $\mathrm{KMnO}_{4}$, the unique structure of montmorillonite effectively prevented the agglomeration of $\mathrm{MnO}_{2}$ resulting in the formation of nano-sized $\mathrm{MnO}_{2}$ particles. The clay mineral-templated $\mathrm{MnO}_{2}$ showed higher reactivity compared to nano- $\mathrm{MnO}_{2}$ prepared by conventional method as indicated by the oxidation of bisphenol A (BPA). Over $90 \%$ of BPA could be degraded within 10 min at $\mathrm{pH} 4.0$ containing $250 \mathrm{mg} \mathrm{L}^{-1}$ montmorillonite $\left(109 \mu \mathrm{M} \mathrm{MnO}_{2}\right)$ and $21.9 \mu \mathrm{M}$ BPA. The presence of humic acid showed significant enhancement on BPA removal under acidic condition, while slight inhibition under alkaline condition. Due to the ubiquitous distribution of montmorillonite in natural environment, montmorillonite templated $\mathrm{MnO}_{2}$ would offer the potential for in situ remediation of many organic contaminants.

Keyword: Clay mineral-templated $\mathrm{MnO}_{2}$; Bisphenol A; Montmorillonite; Humic acid; nanoscale $\mathrm{MnO}_{2}$ 


\section{Introduction}

Manganese dioxide $\left(\mathrm{MnO}_{2}\right)$ is one of the mostly studied strong oxidants for degradation of various of organic pollutants, e.g., steroid estrogens (Xu et al., 2008), oxytetracycline (Rubert and Pedersen, 2010) and lincosamide (Chen et al., 2010). Due to the smaller particle size and higher specific surface area, nanoscale $\mathrm{MnO}_{2}$ has drawn considerable attentions and has been utilized to degrade organic pollutants in green infrastructure and water treatment (Remucal and Ginder-Vogel, 2014). Various synthesis methods for nano- $\mathrm{MnO}_{2}$ have been developed, such as sol-gel process (Giraldo et al., 2000), hydrothermal synthesis (Subramanian et al., 2005) and thermal decomposition (Lamaita et al., 2005). However, during the process of synthesis, $\mathrm{MnO}_{2}$ nanoparticles prone to cause agglomeration resulting in larger particles with reduced activity (Lin et al., 2009 and Zhao et al., 2006). Therefore, many strategies have been tested to stabilize the synthesized nano- $\mathrm{MnO}_{2}$ to prevent further aggregation. Activated carbon fibers were used as stabilizer to increase $\mathrm{MnO}_{2}$ particles dispersion, which enhanced the catalytic oxidation efficiency to convert NO into $\mathrm{NO}_{2}$ remarkably (Wang et al., 2014). Moreover, bovine serum albumin stabilized $\mathrm{MnO}_{2}$ nanoparticles exhibited high peroxidase-, oxidase-, and catalase-like activities (Liu et al., 2012). $\mathrm{MnO}_{2}$ nanosheets using grapheme oxide as the template exhibited high activity for the degradation of methylene blue (Zhao et al., 2013).

Montmorillonites are ubiquitous in subsoils, sediments and soils. Depending on the exchangeable cations, the layer spacings of montmorillonites generally vary from 
1 to 1.8 nanometers, and the width is in the range between a few tens and a few hundreds nanometers. The specific surface areas of montmorillonites is $800 \mathrm{~m}^{2} \mathrm{~g}^{-1}$ (Schoonheydt, 2002). Hence, montmorillonite can be considered as a natural nanomaterial. Because of isomorphic substitution, montmorillonites possess structural negative charges, which are compensated by exchangeable cations in the interlayer. Our previous studies showed that montmorillonite could be used as a template to synthesize subnano-sized zero valent iron (ZVI) (Gu et al., 2010 and Zhang et al., 2015). Due to the special structure of montmorillonite, ZVIs could be synthesized in interlayer region of montmorillonite with the average size of $0.5 \mathrm{~nm}$ (Gu et al., 2010). The montmorillonite templated ZVI exhibits higher efficiency than ZVIs synthesized from traditional methods as indicated by the reductive degradation of nitrobenzene (Gu et al., 2010). With the protection of montmorillonite, the montmorillonite-templated ZVIs also maintain a greater stability ( $\mathrm{Gu}$ et al., 2010). Here, we hypothesize that nano- $\mathrm{MnO}_{2}$ could also be formed in clay mineral interlayer by initially saturating montmorillonite with $\mathrm{Mn}^{2+}$, then via oxidation by addition of $\mathrm{MnO}_{4}{ }^{-}$

Bisphenol A (BPA) is widely used for the production of polycarbonates and other plastics, and has been frequently detected in soils, sediments, air, municipal waste and biota samples (Huang et al., 2012). It has been reported that the concentration of BPA in bottled water could even reach $568 \mathrm{ng} \mathrm{L} \mathrm{L}^{-1}$ (Li et al., 2006). Recent studies showed that BPA could act as an estrogen agonist or antagonist to disrupt cell function (Wozniak et al., 2005 and Lee et al., 2003), which may potentially lead to breast 
cancer (EFSA, 2006). Hence it is greatly needed to develop an environmental-friendly and inexpensive technique to effectively degrade BPA.

The objectives of this study were to develop a new highly reactive montmorillonite based nano- $\mathrm{MnO}_{2}$ and to investigate the degradation process of BPA by montmorillonite supported $\mathrm{MnO}_{2}$. Our results clearly demonstrated that the isolated distribution of exchangeable $\mathrm{Mn}^{2+}$ effectively prevents the agglomeration of formed $\mathrm{MnO}_{2}$ particles upon reaction with $\mathrm{MnO}_{4}^{-}$, and the degradation of BPA by montmorillonite templated $\mathrm{MnO}_{2}$ is significantly enhanced compared to $\mathrm{MnO}_{2}$ prepared by conventional method. Furthermore, the effects of $\mathrm{pH}$ and humic acid on the oxidation of BPA were also evaluated.

\section{Experimental part}

\subsection{Materials}

Analytical grade manganese chloride $\left(\mathrm{MnCl}_{2}\right)$, potassium acetate, 2-(cyclohexylamino) ethanesulfonic acid (CHES), potassium permanganate $\left(\mathrm{KMnO}_{4}\right)$, BPA, 4-morpholinepropanesulfonic acid (MOPS), L-ascorbic acid, silylation reagent N,O-bis(trimethysilyl)trifluoroacetamide (BSTFA) and trimethylchorosilane (TMCS) were purchased from Sigma-Aldrich and the purities of the chemicals were $>98 \%$. Aldrich humic acid was used as the reference humic acid and purchased from Sigma-Aldrich. Acetonitrile and methanol were HPLC grade from Tedia Inc.

\subsection{Preparation of montmorillonite templated $\mathrm{MnO}_{2}$ and $\delta-\mathrm{MnO}_{2}$}

$\mathrm{Mn}^{2+}$ saturated montmorillonite $\left(\mathrm{Mn}^{2+}\right.$-montmorillonite) was prepared according 
to the method of Arroyo et al. (2005). The montmorillonite was supplied from Fenghong Chemical Co. (Zhejiang, China). The carbonate impurities in montmorillonite were removed by titrating the clay mineral dispersion to $\mathrm{pH} 6.8$ using pH 5.0 acetic acid-sodium acetate buffer $(0.5 \mathrm{M})$, then the montmorillonite dispersion was centrifuged at $60 \mathrm{~g}$ for $6 \mathrm{~min}$ to obtain clay mineral sized particles $(<2 \mu \mathrm{m})$. The montmorillonite fraction was redispersed in $0.1 \mathrm{M} \mathrm{MnCl}_{2}$ solution for $8 \mathrm{~h}$ and centrifuged at $3500 \mathrm{~g}$ for $15 \mathrm{~min}$. To ensure full saturation of montmorillonite by $\mathrm{Mn}^{2+}$, this procedure was repeated five more times. The resultant $\mathrm{Mn}^{2+}$-montmorillonite was washed by deionized water until a negative chloride test using $\mathrm{AgNO}_{3}$, then stored at $4{ }^{\circ} \mathrm{C}$ as aqueous dispersion for further use. The manganese content in $\mathrm{Mn}^{2+}$-montmorillonite was determined through $\mathrm{HCl}-\mathrm{HNO}_{3}-\mathrm{HF}$ digestion and then analyzed by atomic absorption spectrophotometer (AAS) (PerkinElmerPinAAcle900T, Shelton, CT). Synthesis of montmorillonite templated $\mathrm{MnO}_{2}$ was based on the redox reaction of $\mathrm{Mn}^{2+}$ ion with potassium permanganate. Briefly, $4 \mathrm{~L}$ of $25 \mathrm{~g} \mathrm{~L}^{-1} \mathrm{Mn}^{2+}$-montmorillonite dispersion was purged with nitrogen and constantly stirred, followed by a dropwise addition of $100 \mathrm{~mL}$ aqueous solution containing $4.6 \mathrm{~g} \mathrm{KMnO}_{4}$ and $2.3 \mathrm{~g} \mathrm{NaOH}$ (molar ratio of $\mathrm{KMnO}_{4} / \mathrm{Mn}^{2+}=2: 3$ ). The formed montmorillonite/ $\mathrm{MnO}_{2}$ dispersion was centrifuged. The montmorillonite dispersion was washed with fresh Milli-Q water until the conductivity of supernatant was below $2 \mu \mathrm{S} \mathrm{cm}^{-1}$. The montmorillonite templated manganese dioxide was stored in aqueous dispersion at $4{ }^{\circ} \mathrm{C}$.

Manganese dioxide $\left(\delta-\mathrm{MnO}_{2}\right)$ was synthesized following the method of Murray 
(Murray, 1974). Briefly, $80 \mathrm{~mL}$ of $0.1 \mathrm{M} \mathrm{KMnO}_{4}$ and $160 \mathrm{~mL}$ of $0.1 \mathrm{M} \mathrm{NaOH}$ were mixed with $1640 \mathrm{~mL}$ of nitrogen-purged water, then $120 \mathrm{~mL}$ of $0.1 \mathrm{M} \mathrm{MnCl}_{2}$ was added dropwisely. The formed $\mathrm{MnO} 2$ particles were allowed to settle down by gravity, then washed with Milli-Q water until the conductivity of supernatant was below $2 \mu \mathrm{S}$ $\mathrm{cm}^{-1}$

\subsection{Characterization of montmorillonite templated $\mathrm{MnO}_{2}$}

$\mathrm{X}$-ray diffraction (XRD) analysis was employed to determine the clay mineral basal spacings. The X-ray diffractometer (Bruker AXS, Germany) was equipped with crystal graphite monochromater and $\mathrm{CuK} \alpha$ radiation $(\lambda=1.5418 \AA)$, operating at 40 $\mathrm{mA}$ and $40 \mathrm{kV}$. X-ray photoelectron spectroscopy (XPS) (UIVAC-PHI Physical Electronics PHI 5000 Versa Probe) was employed to confirm the transformation of $\mathrm{Mn}^{2+}$ to $\mathrm{Mn}^{4+}$ upon the reaction with $\mathrm{MnO}_{4}^{-}$. The X-ray photoelectron spectroscopy equipped with a monochromatic Al X-ray source operated at $20 \mathrm{~mA}$ and $30 \mathrm{kV}$.

Aniline was used as the probe molecule to determine the reaction efficiency of synthesized montmorillonite/ $\mathrm{MnO}_{2}$. Prior studies have demonstrated that during the oxidation of aniline by manganese dioxide, aniline is considered as a 2-equivalent reductants (Laha and Luthy, 1990). The kinetic experiments were performed in $8 \mathrm{~mL}$ glass vials. $5 \mu \mathrm{L}$ of aniline stock solution was added to $5 \mathrm{~mL}$ acetate buffer $(\mathrm{pH}=4)$ containing $2.468 \mathrm{~g} \mathrm{~L}^{-1}$ montmorillonite/ $\mathrm{MnO}_{2}$ to obtain an initial aniline concentration of $1.074 \mathrm{mM}$. The experiment was performed in an anaerobic chamber and all water used in the experiment was fully deoxygenated. At predetermined time intervals, $5 \mu \mathrm{L}$ of L-ascorbic acid solution $\left(50 \mathrm{~g} \mathrm{~L}^{-1}\right)$ was added to terminate the reaction and the vial 
was immediately vortexed for $30 \mathrm{~s}$, followed by addition of $3 \mathrm{~mL}$ methanol and 10 min of vortex to extract the aniline adsorbed on montmorillonite. The concentration of aniline were analyzed separately by a high performance liquid chromatography (HPLC) (Waters Alliance 2695, Milford, MA) monitored at $254 \mathrm{~nm}$ using a photodiode array detector. A $4.6 \times 250 \mathrm{~mm}$ Waters XBridge Shield $\mathrm{C}_{18}$ column was employed for the separation. The isocratic mobile phase consisted of $50 \%$ acetonitrile and $50 \% 0.05 \mathrm{M}$ ammonium acetate. The flow rate is $1.0 \mathrm{~mL} \mathrm{~min}^{-1}$ and the injection volume was $10 \mu \mathrm{L}$.

\subsection{Kinetic experiments for oxidation of BPA}

The degradation experiment was conducted in a $150 \mathrm{~mL}$ glass Erlenmeyer flask at

room temperature $\left(23^{\circ} \mathrm{C}\right)$, which was covered with aluminum foil to avoid direct light irradiation. Reaction mixture $(100 \mathrm{~mL})$ was constantly stirred with a magnetic stir bar at $480 \mathrm{rpm}$. Reaction solution was maintained at constant $\mathrm{pH}$ buffered with $10 \mathrm{mM}$ acetic acid ( $\mathrm{pH} 4-6)$, MOPS ( $\mathrm{pH} 7-8)$, or CHES ( $\mathrm{pH}$ 9) and the corresponding potassium conjugate bases. Reaction was initiated by adding $50 \mu \mathrm{L}$ of BPA methanol stock solution $(43.80 \mathrm{mM})$ into a continuously stirred $100 \mathrm{~mL}$ buffer solution containing $250 \mathrm{mg} \mathrm{L}^{-1}$ montmorillonite $(109 \mu \mathrm{M} \mathrm{MnO})$ with the initial BPA concentration of $21.9 \mu \mathrm{M}$. The volume fraction of methanol in reaction solution was $<$ $0.1 \%$ to minimize the effect of organic solvent on the degradation process. At predetermined time intervals, aliquot of $0.5 \mathrm{~mL}$ of reaction mixture was withdrawn, transferred to $8 \mathrm{~mL}$ glass tubes containing $0.5 \mu \mathrm{L}$ of $\mathrm{L}$-ascorbic acid solution $\left(50 \mathrm{~g} \mathrm{~L}^{-1}\right)$ and vortexed for $30 \mathrm{~s}$, followed by addition of $1 \mathrm{~mL}$ methanol and $10 \mathrm{~min}$ of vortex to 
extract the BPA adsorbed on montmorillonite. After extraction, sample of the montmorillonite dispersion was filtered through $0.45 \mu \mathrm{m}$ regenerated cellulose syringe filters. All samples were analyzed within $24 \mathrm{~h}$. Control experiments confirmed that BPA was stable in the presence of L-ascorbic acid and the efficiency of the extraction method for the adsorbed BPA was nearly $100 \%$, there was no measureable adsorption of BPA in methanol/water mixture by the membrane filters. For comparison, similar experiments were also conducted for $\delta-\mathrm{MnO}_{2}$ prepared by conventional method at $\mathrm{pH}$ 4. The initial concentrations of $\delta-\mathrm{MnO}_{2}$ and $\mathrm{BPA}$ were $109 \mu \mathrm{M}$ and $21.9 \mu \mathrm{M}$, respectively. The concentrations of BPA were determined using the same HPLC system as described above with the UV absorbance at $200 \mathrm{~nm}$. The isocratic mobile phase consisted of 50\% acetonitrile and 50\% water. The flow rate is $1.0 \mathrm{~mL} \mathrm{~min}^{-1}$ and the injection volume was $25 \mu \mathrm{L}$. The released $\mathrm{Mn}^{2+}$ concentration in solution during the reaction was also analyzed by AAS.

For reaction product identification, the reaction mixture was extracted by $100 \mathrm{~mL}$ methylene chloride using a rotary shaker at a rate of $250 \mathrm{rpm}$ for $3 \mathrm{~h}$, then silylated by adding BSTFA + TMCS (99:1) and analyzed by the Thermo gas chromatograph fitted with a mass spectrometer (GC-MS) on full scan mode. Helium was the carrier gas at a flow rate of $1 \mathrm{~mL} \mathrm{~min}^{-1}$. The oven temperature was setted from $60{ }^{\circ} \mathrm{C}$ ( 2 min hold $)$ to $200{ }^{\circ} \mathrm{C}\left(20^{\circ} \mathrm{C} \min ^{-1}, 5\right.$ min hold $)$, and then to $300{ }^{\circ} \mathrm{C}\left(15^{\circ} \mathrm{C} \min ^{-1}, 20\right.$ min hold $)$.

\subsection{Effect of humic acid}

The effect of humic acid on the degradation of BPA by montmorillonite/ $\mathrm{MnO}_{2}$ was investigated at $\mathrm{pH} 4.0,7.0$ and 9.0 with two humic acid concentrations (5 and 20 
mg $\mathrm{C} \mathrm{L}^{-1}$ ) under similar reaction conditions. The adsorption kinetic experiments of aldrich humic acid $\left(5 \mathrm{mg} \mathrm{C} \mathrm{L}^{-1}\right)$ on montmorillonite/ $\mathrm{MnO}_{2}\left(250 \mathrm{mg} \mathrm{L}^{-1}\right)$ at different pHs during the reaction period (100 min) were also studied. At designated time, the samples were centrifuged at $3295 \mathrm{~g}$ for $5 \mathrm{~min}$ and the supernatants were decanted and collected. The concentration of humic acid in supernatants was analyzed by a total organic carbon analyzer (TOC-5000A, Shimadzu Corp, Kyoto, Japan). To test whether humic acid was adsorbed into the interlamellar space of the clay mineral, the samples after adsorption were centrifuged and the clay mineral pastes were collected and freeze-dried for XRD analysis.

\section{Results and discussion}

\subsection{Characterization of montmorillonite templated $\mathrm{MnO}_{2}$}

The manganese content in $\mathrm{Mn}^{2+}$-montmorillonite was determined to be $2.4 \% \mathrm{w} / \mathrm{w}$ (Table S1). Addition of $\mathrm{KMnO}_{4}$ caused the oxidation of $\mathrm{Mn}^{2+}$ to $\mathrm{Mn}^{4+}$, and the negative charges of the montmorillonites became compensated by $\mathrm{K}^{+}$from the added $\mathrm{KMnO}_{4}$. The formation of $\mathrm{MnO}_{2}$ from $\mathrm{Mn}^{2+}$ proceeds according to the following reaction:

$$
2 \mathrm{MnO}_{4}{ }^{-}+3 \mathrm{Mn}^{2+}+2 \mathrm{H}_{2} \mathrm{O}=5 \mathrm{MnO}_{2}+4 \mathrm{H}^{+}
$$

The XRD patterns of $\mathrm{Mn}^{2+}$-montmorillonite, $\mathrm{K}^{+}$-montmorillonite and montmorillonite/ $\mathrm{MnO}_{2}$ are showed in Figure 1. The basal spacings of $\mathrm{Mn}^{2+}$-montmorillonite and $\mathrm{K}^{+}$-montmorillonite are 14.8 and $11.3 \AA$, respectively. During the oxidation of the $\mathrm{Mn}^{2+}$-clay mineral with $\mathrm{KMnO}_{4}$, it is expected that most $\mathrm{Mn}^{2+}$ that had previously compensated cation-exchange sites on the montmorillonite 
would be replaced by $\mathrm{K}^{+}$. After oxidation, due to the XRD peak for montmorillonite occurs at basal spacing greater than $11.3 \AA, \mathrm{MnO}_{2}$ controls the basal spacing of the oxidized clay mineral system, the basal spacing increased to $12.2 \AA$. The approximate thickness of a montmorillonite sheet alone is $9.6 \AA$ (Johnson et al. 1988), hence the vertical thickness of formed $\mathrm{MnO}_{2}$ particles in the clay interlayer is $\sim 2.6 \AA$, which is great smaller than nano- $\mathrm{MnO}_{2}$ synthesized from traditional methods (Murray, 1974), indicating higher surface area and more active reaction sites, hence exhibiting higher reactivity (Gu et al., 2010 and Zhang et al., 2015).

Based on the XPS spectra reported in the literature (Table S2), the broad peaks of binding energies for $\mathrm{Mn}^{2+}$-montmorillonite $\left(2 \mathrm{p}_{1 / 2}=653.4 \mathrm{eV}\right.$ and $\left.2 \mathrm{p}_{3 / 2}=642.1 \mathrm{eV}\right)$ indicate that $\mathrm{Mn}^{2+}$ has been partially oxidized (Figure 2) (Chen and Hsu, 2014). For montmorillonite/ $\mathrm{MnO}_{2}$, the XPS spectrum is consistent with the assignments by other researchers (Subramanian et al., 2005 and Liu et al., 2013), supporting that most of the $\mathrm{Mn}^{2+}$ is converted to $\mathrm{Mn}^{4+}$ (Figure 2).

Previous studies showed that $\mathrm{MnO}_{2}$ was active in the oxidative transformation of aromatic amine compounds (Laha and Luthy, 1990 and Henbest and Thomas, 1957). In the reaction of aniline with $\mathrm{MnO}_{2}$, the reaction products were $\mathrm{Mn}^{2+}$ and azobenzene, and for one aniline two electrons are transferred (Laha and Luthy, 1990). Therefore, the amount of aniline degraded could be used to estimate the reactivity of the synthesized $\mathrm{MnO}_{2}$ (Laha and Luthy, 1990). To evaluate the reactivity of the $\mathrm{MnO}_{2}$ in clay mineral interlayer, the initial concentration of aniline $(1.074 \mathrm{mM})$ was equal to the oxidation potential of the total manganese content of the montmorillonite, that is, 
a 1:1 molar ratio of aniline/Mn was used. Within ten minutes, $\sim 69 \%$ of aniline had been oxidized. After $\sim 30 \mathrm{~min}$, the reaction reached equilibrium with the maximum efficiency of $\sim 80 \%$ (Figure S1). This high oxidation efficiency can only be achieved if all of the $\mathrm{Mn}^{2+}$ was oxidized to $\mathrm{MnO}_{2}$ when the $\mathrm{KMnO}_{4} / \mathrm{Mn}(\mathrm{II})$ molar ratio was 2:3, which implies that the manganese in clay interlayer is predominantly $\mathrm{MnO}_{2}$.

\subsection{Degradation of BPA by montmorillonite templated $\mathrm{MnO}_{2}$}

Control experiment showed that in the absence of montmorillonite templated $\mathrm{MnO}_{2}$, there is negligible degradation of BPA under our experimental conditions. However, as a certain amount of montmorillonite/ $\mathrm{MnO}_{2}$ was added, BPA was degraded rapidly. A time course of BPA removal by montmorillonite templated $\mathrm{MnO}_{2}$ is shown in Figure 3. About $90 \%$ of BPA could be oxidized in $10 \mathrm{~min}$ at $\mathrm{pH} 4.0$, containing $250 \mathrm{mg} \mathrm{L}^{-1}$ montmorillonite/ $\mathrm{MnO}_{2}(109 \mu \mathrm{M} \mathrm{MnO})$ and $21.9 \mu \mathrm{M}$ BPA. In contrast, only $27 \%$ of BPA can be degraded in 100 min in the presence of $109 \mu \mathrm{M}$ $\delta-\mathrm{MnO}_{2}$ and $21.9 \mu \mathrm{M}$ BPA under similar reaction conditions. The comparison of reactivity for the oxidation of organic contaminants by different forms of $\mathrm{MnO}_{2}$ is listed in Table $\mathrm{S} 3$, which shows that montmorillonite/ $\mathrm{MnO}_{2}$ developed in this study is more reactive. The high reactivity of montmorillonite templated $\mathrm{MnO}_{2}$ could be attributed to the discrete distribution of $\mathrm{MnO}_{2}$ on the interlayer surfaces of montmorillonite resulting in a much smaller particle size than $\delta-\mathrm{MnO}_{2}$. Interestingly, only limited release of $\mathrm{Mn}^{2+}(\sim 4 \%)$ during the reaction was observed, it could be explained by the adsorption of $\mathrm{Mn}^{2+}$ ion on the surface of clay mineral due to the negative surface charge. 
As shown in Figure 4, the degradation of BPA by montmorillonite/ $\mathrm{MnO}_{2}$ is strongly $\mathrm{pH}$-dependent. The estimated pseudo first-order reaction rate constants are $0.174,0.042,0.029,0.024,0.016$ and $0.008 \mathrm{~min}^{-1}$ for $\mathrm{pHs}$ of $4.0,5.0,6.0,7.0,8.0$ and 9.0, respectively (Table S4). Overall, the BPA removal rates at different pHs decrease as the increase of $\mathrm{pH}$, suggesting that acidic condition enhances the transformation of BPA. Similar results were also observed for the oxidation of methylene blue (Zhu et al., 2010) and BPA (Lin et al., 2013) by $\mathrm{MnO}_{2}$. It has been reported that lower $\mathrm{pH}$ could increase the reduction potential of manganese dioxide (Lin et al., 2013). As indicated by the following reaction:

$$
\mathrm{MnO}_{2}(\mathrm{~s})+4 \mathrm{H}^{+}+2 \mathrm{e}^{-}=\mathrm{Mn}^{2+}+2 \mathrm{H}_{2} \mathrm{O}
$$

protons are essential to reduce $\mathrm{MnO}_{2}$ to $\mathrm{Mn}^{2+}$, which could explain the $\mathrm{pH}$ dependence of BPA degradation by montmorillonite/ $\mathrm{MnO}_{2}$.

\subsection{Effect of humic acid on BPA degradation}

Humic acids are natural macromolecules, which are widely distributed in the environment. Previous studies have shown that the presence of humic acid would significantly affect the oxidation processes of many organic contaminants by $\mathrm{MnO}_{2}$ (Chen et al. 2010, Zhu et al. 2010). In this research, the effect of humic acid on the oxidation of BPA by montmorillonite templated $\mathrm{MnO}_{2}$ shows different behavior at different pHs (Figure 5), which might be explained by the interaction between montmorillonite and humic acid. At $\mathrm{pH} 4$, the pseudo first-order reaction rate constants are $0.174,0.447$ and $0.495 \mathrm{~min}^{-1}$ for humic acid concentrations of $0,5.0$ and $20.0 \mathrm{mg} \mathrm{C} \mathrm{L}^{-1}$, respectively (Table S5), indicating that under acidic condition $(\mathrm{pH}=4)$, 
humic acid could facilitate the degradation of BPA. However, with $\mathrm{pH}$ increase $(\mathrm{pH}=$ 7 and 9), the presence of humic acid starts to inhibit the oxidation process (Figure 5 and Table S5). Humic acid adsorption from water by $\mathrm{MnO}_{2}$-clay mineral at several $\mathrm{pH}$ values is presented in Figure 6. In general, adsorption decreases as the increase of clay mineral dispersion $\mathrm{pH}$. It is well known that humic acid carries a variety of functional groups, such as phenolic groups and carboxylic. At low $\mathrm{pH}$ (below $\mathrm{p} K_{a}$ of the functional groups), humic acid gets protonated so that it becomes a neutral more or less hydrophobic molecule. Such polymeric molecules can be more easily adsorbed into the interlayer of clay minerals (Schnitze and Kodama, 1966 and Martinez and Rodriguez, 1969), it is also supported from our XRD results (Table S6). At pH 4, after the adsorption of humic acid onto montmorillonite, the d-spacing increases from 12.2 $\AA$ to $13.7 \AA$ (Table S6). Humic acids are generally considered as the strong chelating agents for metals (e.g. $\mathrm{Cu}, \mathrm{Pb}$ and $\mathrm{Cd}$ ) (Christl et al., 2001 and Liu and Gonzalez, 2000), and the phenolic and carboxylic groups are mainly the active binding sites (Liu and Gonzalez, 2000). During the oxidation process, as $\mathrm{MnO}_{2}$ is converted to $\mathrm{Mn}^{2+}$, it is expected that the humic acid molecules in the interlayer would complex with $\mathrm{Mn}^{2+}$ to prevent the accumulation of $\mathrm{Mn}^{2+}$ on $\mathrm{MnO}_{2}$ surfaces and make the reactive sites more accessible (Xu et al., 2008 and Kang et al., 2004), which could explain the positive effect of humic acid at low $\mathrm{pH}$. With the increase of $\mathrm{pH}$ (neutral or alkaline), the phenolic groups and carboxylic of humic acid dissociate, causing the repulsion between the negatively charged clay mineral and humic acid molecules. In this case, humic acid is mainly associated with montmorillonite on the external surface of the 
mineral, it is also consistent with our experimental observation and the XRD results, no increase of d-spacing was observed at pH 7 and 9 (Table S6). The humic acid on the external surface might block the edge of clay mineral and decrease the possibility of BPA entering the internal surface to react with $\mathrm{MnO}_{2}$.

\subsection{Reaction intermediates}

The reaction products were identified by GC-MS after the samples were extracted by methylene chloride and subsequent silylation. Only two major reaction products were detected, and other minor coupling products were also identified. The GC chromatogram and mass spectra of the major reaction products are shown in Figure S2. Products B and C correspond to the same molecule, depending on the extent of silylation. Both of the two reaction products (products A and B) are from the decomposition of BPA. Product D could be considered as the oxidation product of L-ascorbic. The oxidative degradation of L-ascorbic could form two major intermediates, L-xylonic acid and L-lyxonic acid (Yamabe et al., 2015), so we speculate that product D was formed via coupling of the intermediates. The products observed in this study were consistent with the oxidative transformation of BPA by $\mathrm{MnO}_{2}$ dispersion, and the detailed reaction pathway had been proposed by Lin et al. (Lin et al., 2009).

\section{Conclusions}

In this research, a novel method was developed to synthesize $\mathrm{MnO}_{2}$ using montmorillonite as template. As montmorillonite surface serves as the support, small isolated regions of $\mathrm{MnO}_{2}$ have been formed when $\mathrm{Mn}^{2+}$-clay mineral is oxidized by 
$\mathrm{KMnO}_{4}$ due to the discrete distribution of negative charge sites on montmorillonite. The enhanced oxidation efficiency and high reactivity of montmorillonite-templated $\mathrm{MnO}_{2}$ compared to pure $\delta-\mathrm{MnO}_{2}$ provide the evidence for the small size of $\mathrm{MnO}_{2}$. Aniline oxidation experiments indicate that $\sim 80 \%$ of the $\mathrm{MnO}_{2}$ reactivity can be retained. The newly formed clay mineral templated $\mathrm{MnO}_{2}$ also demonstrated a high reactivity when BPA was used as the model compound.

Montmorillonites are natural environmental materials and the montmorillonite-templated $\mathrm{MnO}_{2}$ could be potentially utilized for in situ treatment of variable contaminants, such as steroid estrogens and antibiotics via oxidation by $\mathrm{MnO}_{2}$. In addition, since most of $\mathrm{Mn}^{2+}$ converted from $\mathrm{MnO}_{2}$ during the reaction is retained by montmorillonite clay mineral, it not only prevents the toxic effect of released $\mathrm{Mn}^{2+}$, but also makes possible to reuse $\mathrm{Mn}^{2+}$ by simply addition of $\mathrm{KMnO}_{4}$ to regenerate montmorillonite/ $\mathrm{MnO}_{2}$.

\section{Acknowledgements}

This work was financially supported by the National Key Basic Research Program of China (2014CB441102), National Science Foundation of China (grants 21237002 and 21477051), and the Collaborative Innovation Center for Regional Environmental Quality. We thank the Analytical Center of Nanjing University for the characterization of samples. 


\section{Appendix A. Supplementary data}

The following are the supplementary data related to this article.

\section{Reference}

Arroyo, L.J., Li, H., Teppen, B.J., Boyd, S.A., 2005. A simple method for partial purification of reference clays. Clays Clay Miner. 53, 512-520.

Chen, W., Ding, Y., Johnston, C.T., Teppen, B.J., Boyd, S.A., Li, H., 2010. Reaction of lincosamide antibiotics with manganese oxide in aqueous solution. Environ. Sci. Technol. 44, 4486-4492.

Chen, H.Y., Hsu, D.J., 2014. X-ray photoelectron spectroscopy studies the cation valencies and distributions in crednerite- $\mathrm{Cu}_{1.1} \mathrm{Mn}_{0.9} \mathrm{O}_{2}$ think films. J. Alloys Comp. $598,23-26$.

Christl, I., Milne, C.J., Kinniburgh, D.G., Kretzschmar, R., 2001. Relating ion binding by fulvic and humic acids to chemical composition and molecular size. 2. metal binding. Environ. Sci. Technol. 35, 2512-2517.

EFSA, E., 2006. Opinion of the scientific panel on food additives, flavourings, processing aids and materials in contact with food on a request from the commission related to 2, 2-bis (4-hydroxyphenyl) propane (bisphenol A). EFSA J. 428, 1-75.

Giraldo, O., Marquez, M., Brock, S.L., Suib, S.L., Hillhouse, H., Tsapatsis, M., 2000. Spontaneous formation of inorganic helical fibers and rings. J. Am. Chem. Soc. 122, 12158-12163. 
Gu, C., Jia, H., Li, H., Teppen, B.J., Boyd, S.A., 2010. Synthesis of highly reactive subnano-sized zero-valent iron using smectite clay templates. Environ. Sci. Technol. 44, 4258-4263.

Henbest, H.B., Thomas, A., 1957. Amine oxidation. part I. the side-chain oxidation of n-alkyl- and nn-dialkyl-anilines by manganese dioxide. J. Chem. Soc. 591, 3032-3039.

Huang, Y.Q., Wong, C.K.C., Zheng, J.S., Bouwman, H., Barra, R., Wahlstrom, B., Neretin, L., Wong, M.H., 2012. Bisphenol A (BPA) in China: a review of sources, environmental levels, and potential human health impacts. Environ. Int. 42, 91-99.

Johnson, I.D., Werpy, T.A., Pinnavaia, T.J., 1988. Tubular silicate-layered silicate intercalation compounds: a new family of pillared clays. J. Am. Chem. Soc. 110, $8545-8547$.

Kang, K.H., Dec, J., Park, H., Bollag, J.M., 2004. Effect of phenolic mediators and humic acid on cyprodinil transformation in presence of birnessite. Water Res. 38, 2737-2745.

Laha, S., Luthy, R.G., 1990. Oxidation of aniline and other primary aromatic amines by manganese dioxide. Environ. Sci. Technol. 24, 363-373.

Lamaita, L., Peluso, M.A., Sambeth, J.E., Thomas, H.J., 2005. Synthesis and characterization of manganese oxides employed in VOCs abatement. Appl. Catal. B-Environ. 61, 114-119.

Lee, H.J., Chattopadhyay, S., Gong, E.Y., Ahn, R.S., Lee, K., 2003. Antiandrogenic effects of bisphenol A and nonylphenol on the function of androgen receptor. Toxicol. Sci. $75,40-46$.

Li, L., Yang, X., Wang, L., 2006. Determination of bisphenol A in bottle water by high performance liquid chromatography. Pract Prev Med 13, 429-430.

Lin, K., Liu, W., Gan, J., 2009. Oxidative removal of bisphenol A by manganese dioxide: efficacy, products, and pathways. Environ. Sci. Technol. 43, 3860-3864.

Lin, K.D., Peng, Y.W., Huang, X.W., Ding, J.F., 2013. Transformation of bisphenol A by manganese oxide-coated sand. Environ Sci Pollut Res. 20, 1461-1467.

Liu, A.G., Gonzalez, R.D., 2000. Modeling adsorption of copper(II), cadmium(II) and 
lead(II) on purified humic acid. Langmuir 16, 3902-3909.

Liu, C., Wang, J., Tian, J., Xiang, L., 2013. Synthesis and surface characterization of $\gamma-\mathrm{MnO}_{2}$ nanostructures. J. Nanomater. 2013, 1-6.

Liu, X., Wang, Q., Zhao, H.H., Zhang, L.C., Su, Y.Y., Lv, Y., 2012. BSA-templated $\mathrm{MnO}_{2}$ nanoparticles as both peroxidase and oxidase mimics. Analyst 137, 4552-4558.

Martinez, F.M., Rodriguez, J., 1969. Interlamellar adsorption of a blackearth humic acid on Na-montmorillonite. J. Plant Nutr. Soil Sci. 124, 52-57.

Murray, J.W., 1974. The surface chemistry of hydrous manganese dioxide. J. Colloid Interface Sci. 46, 357-371.

Remucal, C.K., Ginder-Vogel, M., 2014. A critical review of the reactivity of manganese oxides with organic contaminants. Environ. Sci.: Processes Impacts. 16, $1247-1266$.

Rubert, K.I., Pedersen, J.A., 2010. Kinetics of oxytetracycline reaction with a hydrous manganese oxide. Environ. Sci. Technol. 44, 6522-6522.

Schnitze, M., Kodama, H., 1966. Montmorillonite: effect of $\mathrm{pH}$ on its adsorption of a soil humic compound. Science 153, 70-71.

Schoonheydt, R.A., 2002. Smectite-type clay minerals as nanomaterials. Clays. Clay Miner. 50, 411-420.

Subramanian, V., Zhu, H.W., Vajtai, R., Ajayan, P.M., Wei, B.Q., 2005. Hydrothermal synthesis and pseudocapacitance properties of $\mathrm{MnO}_{2}$ nanostructures. J. Phys. Chem. B. $109,20207-20214$.

Wang, M.X., Liu, H.N., Huang, Z.H., Rang, F.Y., 2014. Activated carbon fibers loaded with $\mathrm{MnO}_{2}$ for removing $\mathrm{NO}$ at room temperature. Chem. Eng. J. 256, 101-106.

Wozniak, A.L., Bulayeva, N.N., Watson, C.S., 2005. Xenoestrogens at picomolar to nanomolar concentrations trigger membrane estrogen receptor- $\alpha$-mediated $\mathrm{Ca}^{2+}$ fluxes and prolactin release in GH3/B6 pituitary tumor cells. Environ. Health Perspect. 113, 431-439.

Xu, L., Xu, C., Zhao, M., Qiu, Y., Sheng, G.D., 2008. Oxidative removal of aqueous 
steroid estrogens by manganese oxides. Water Res. 42, 5038-5044.

Yamabe, S., Tsuchida, N., Yamazaki, S., Sakaki, S., 2015. Frontier orbitals and transition states in the oxidation and degradation of L-ascorbic acid: a DFT study. Org. Biomol. Chem. 13, 4002-4015.

Zhang, Q.J., Guo, Y., Huang, M.Y., Li, H., Gu, C., 2015. Degradation of selected polychlorinated biphenyls by montmorillonite clay-templated $\mathrm{Fe}^{0} / \mathrm{Ni}^{0}$ bimetallic system. Chem. Eng. J. 276, 122-129.

Zhao, G., Li, J., Ren, X., Hu, J., Hu, W., Wang, X., 2013. Highly active $\mathrm{MnO}_{2}$ nanosheet synthesis from graphene oxide templates and their application in efficient oxidative degradation of methylene blue. RSC Adv. 3, 12909-12914.

Zhao, L., Yu, Z., Peng, P.A., Huang, W., Feng, S., Zhou, H., 2006. Oxidation kinetics of pentachlorophenol by manganese dioxide. Environ. Toxicol. Chem. 25, 2912-2919. Zhu, M.X., Wang, Z., Xu, S.H., Li, T., 2010. Decolorization of methylene blue by $\delta$ - $\mathrm{MnO}_{2}$-coated montmorillonite complexes: emphasizing redox reactivity of Mn-oxide coatings. J. Hazard. Mater. 181, 57-64. 


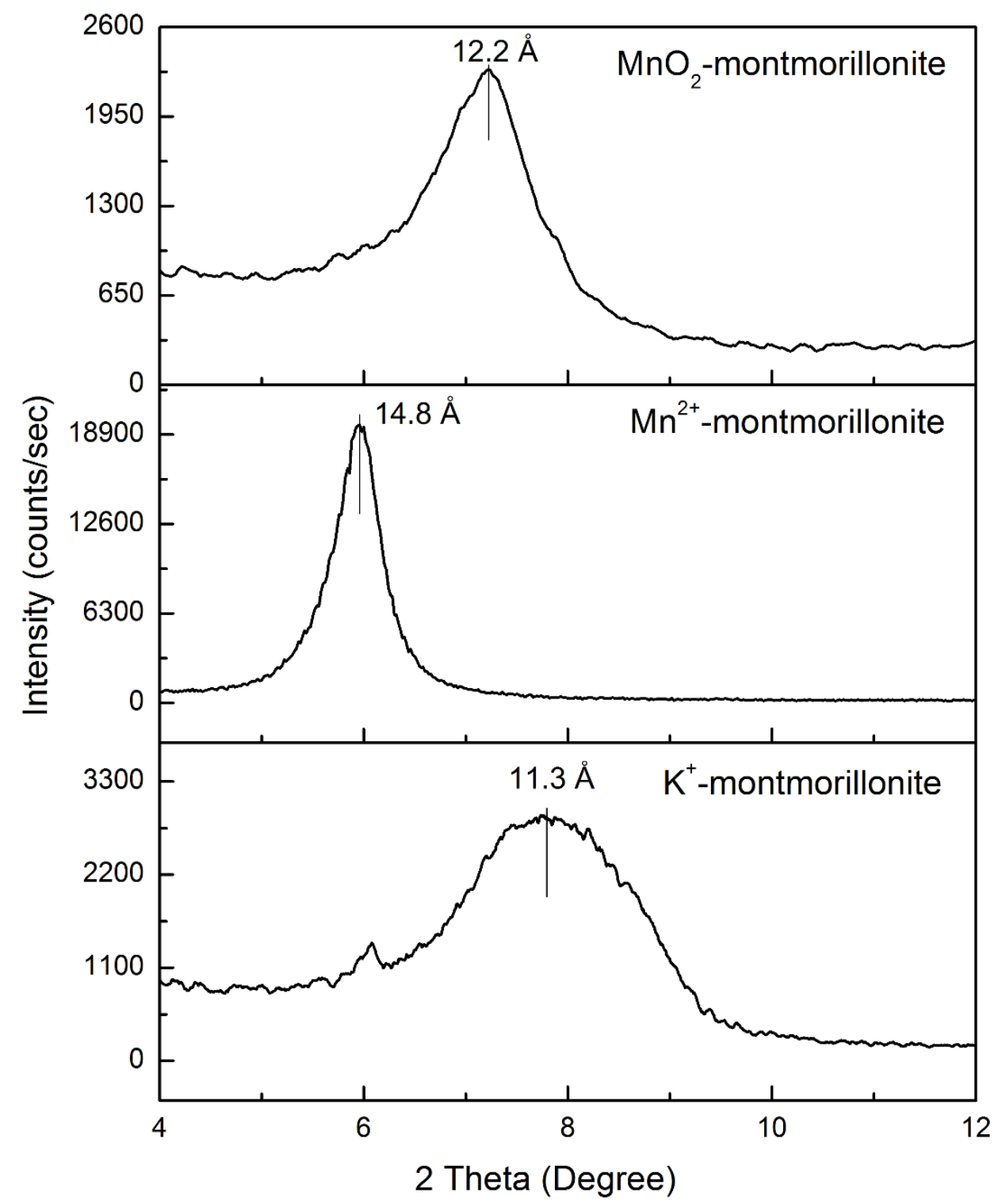

Figure 1. X-ray diffraction patterns of $\mathrm{Mn}^{2+}$-montmorillonite, $\mathrm{K}^{+}$-montmorillonite, and montmorillonite $/ \mathrm{MnO}_{2}$. Two Theta represents the diffracted angle relative to the incident X-ray beam. 

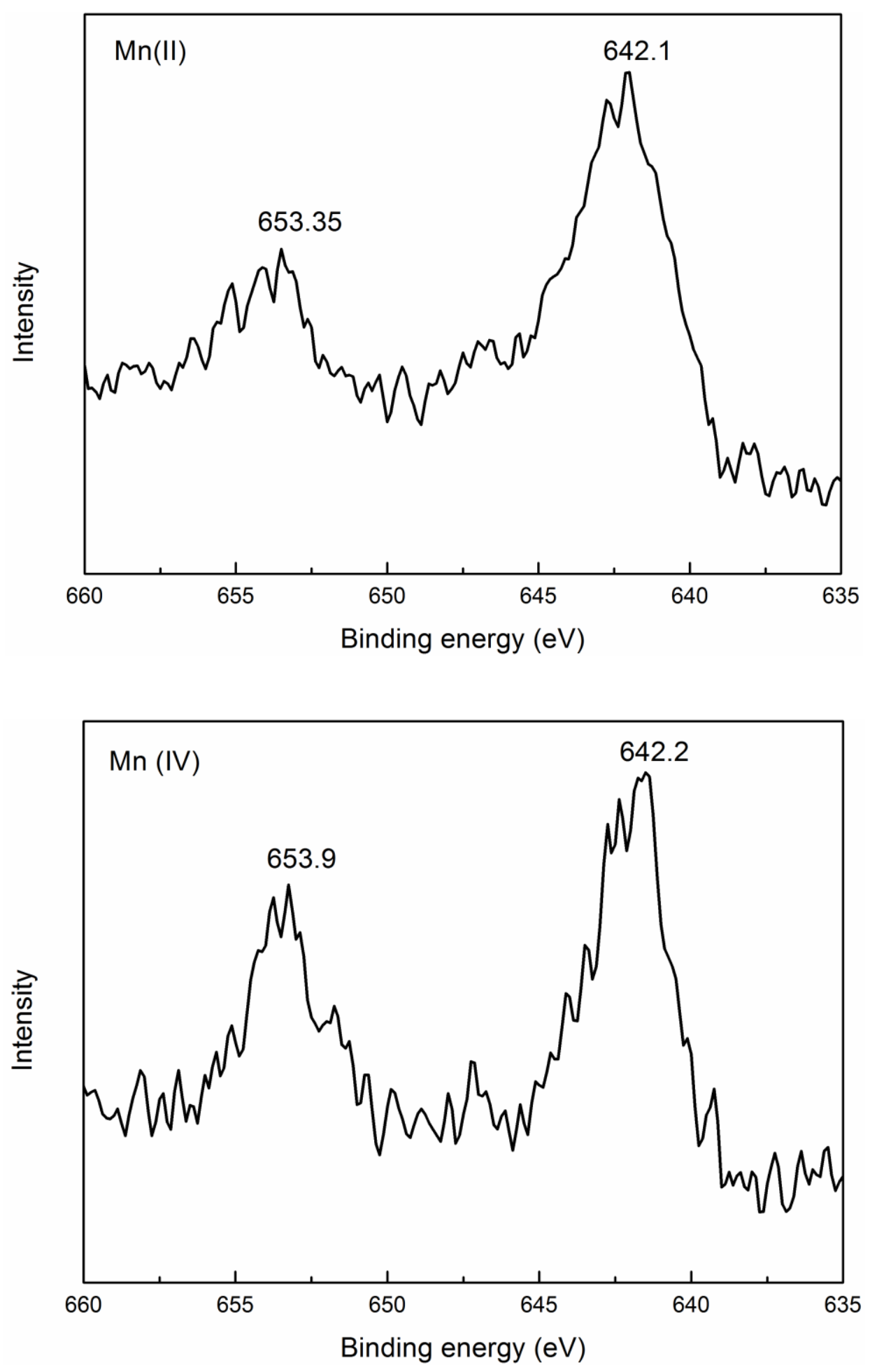

Figure 2. X-ray photoelectron spectra of $\mathrm{Mn}^{2+}$-montmorillonite and montmorillonite/ $\mathrm{MnO}_{2}$. 


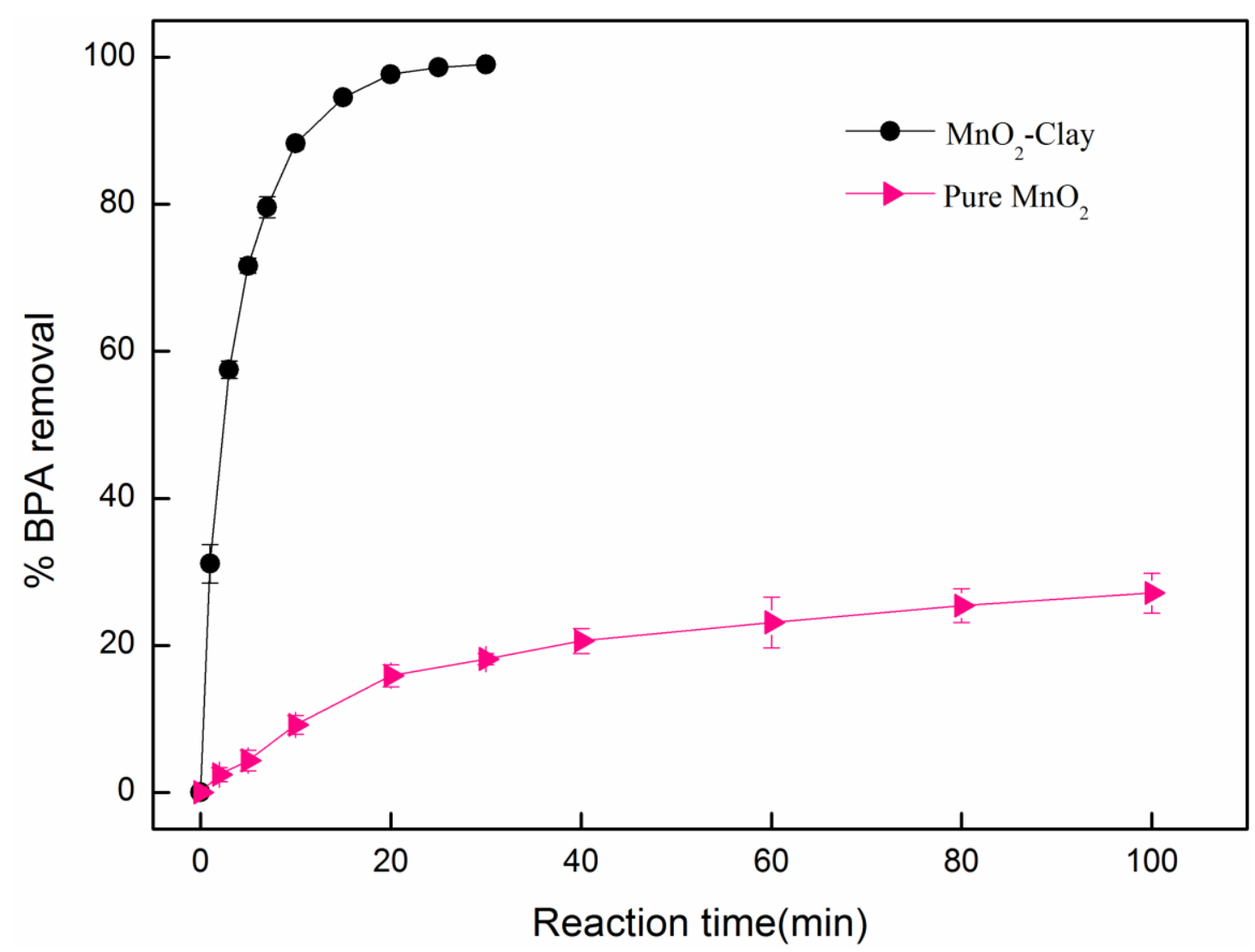

Figure 3. Degradation of BPA by montmorillonite clay templated $\mathrm{MnO}_{2}$ and pure $\delta-\mathrm{MnO}_{2}$ at $\mathrm{pH}$ 4. Experimental conditions: initial bisphenol A, clay, and interlayer $\mathrm{MnO}_{2}$ concentrations of $21.9 \mu \mathrm{M}, 0.25 \mathrm{~g} \mathrm{~L}^{-1}$ and $109 \mu \mathrm{M}$, respectively; initial BPA and pure $\delta-\mathrm{MnO}_{2}$ concentrations of $21.9 \mu \mathrm{M}$ and $109 \mu \mathrm{M}$, respectively. Error bars are the standard deviations of triplicate analyses. 


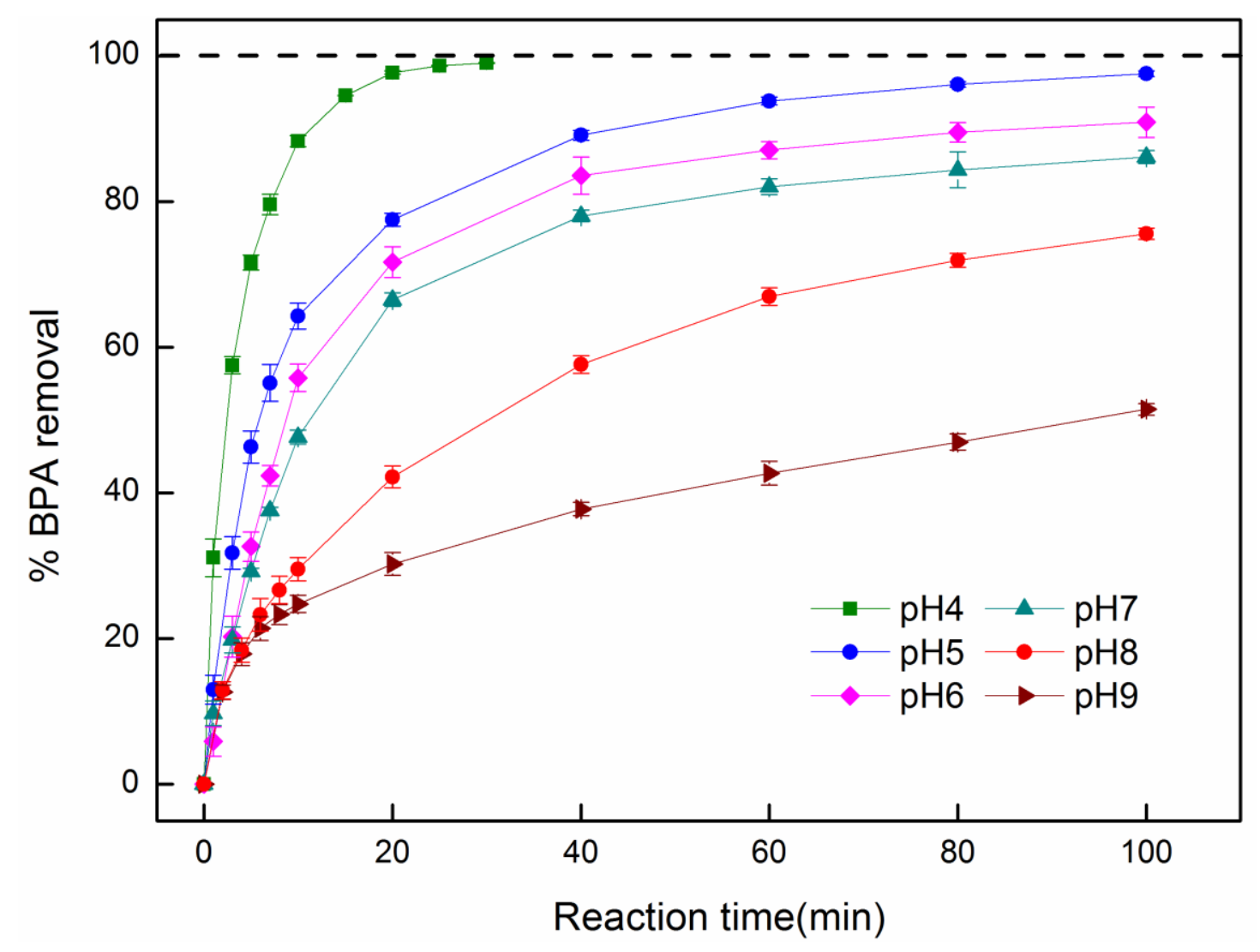

Figure 4. Effect of $\mathrm{pH}$ on BPA removal by montmorillonite clay templated $\mathrm{MnO}_{2}$. Experimental conditions: initial BPA, montmorillonite and $\mathrm{MnO}_{2}$ concentrations of $21.9 \mu \mathrm{M}, 0.25 \mathrm{~g} \mathrm{~L}^{-1}$ and $109 \mu \mathrm{M}$, respectively. Error bars are the standard deviations of triplicate analyses. 


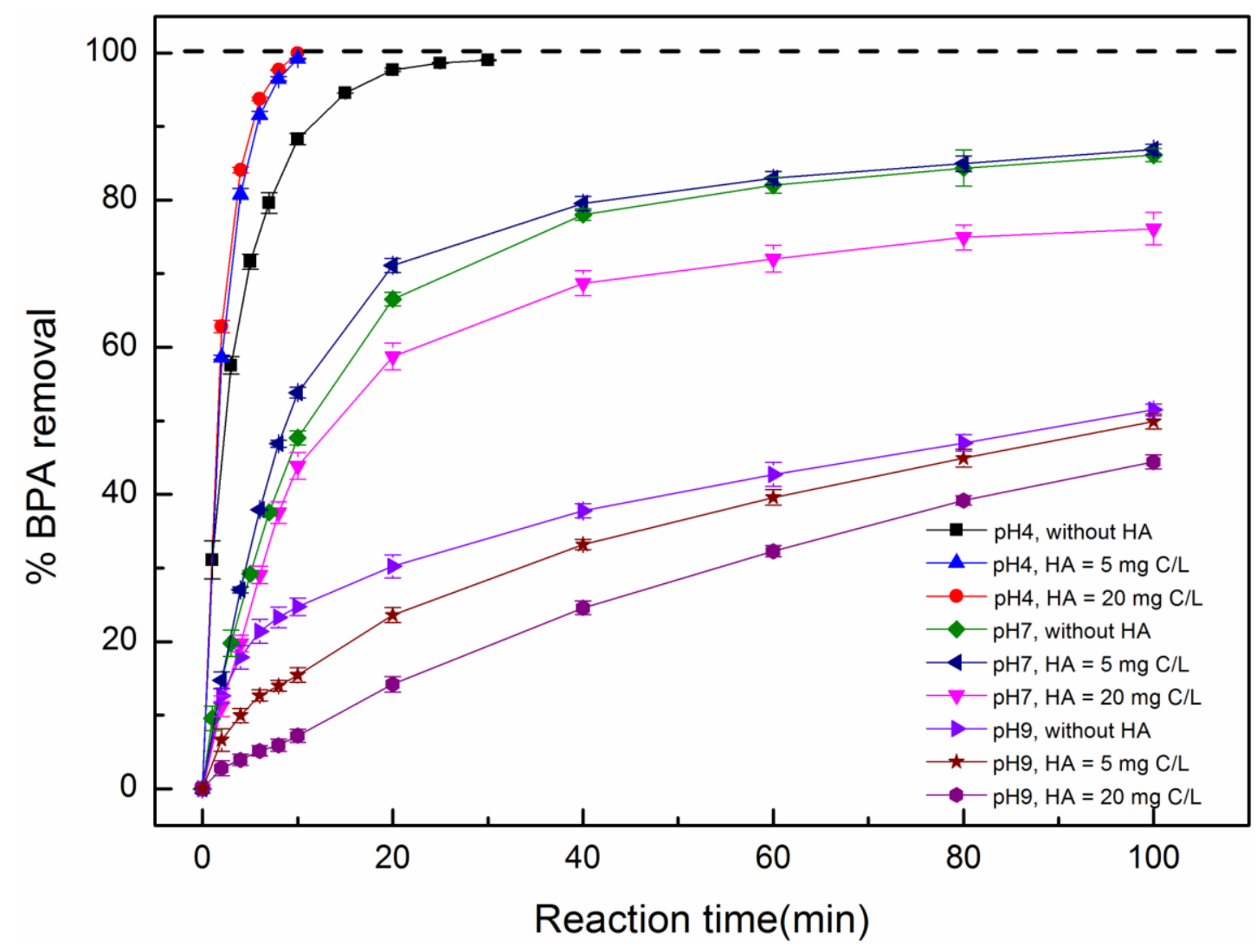

Figure 5. Effect of humic acid on BPA removal by montmorillonite clay templated $\mathrm{MnO}_{2}$. Experimental conditions: initial BPA, montmorillonite and $\mathrm{MnO}_{2}$ concentrations of $21.9 \mu \mathrm{M}, 0.25 \mathrm{~g} \mathrm{~L}^{-1}$ and $109 \mu \mathrm{M}$, respectively. Error bars are the standard deviations of triplicate analyses. 


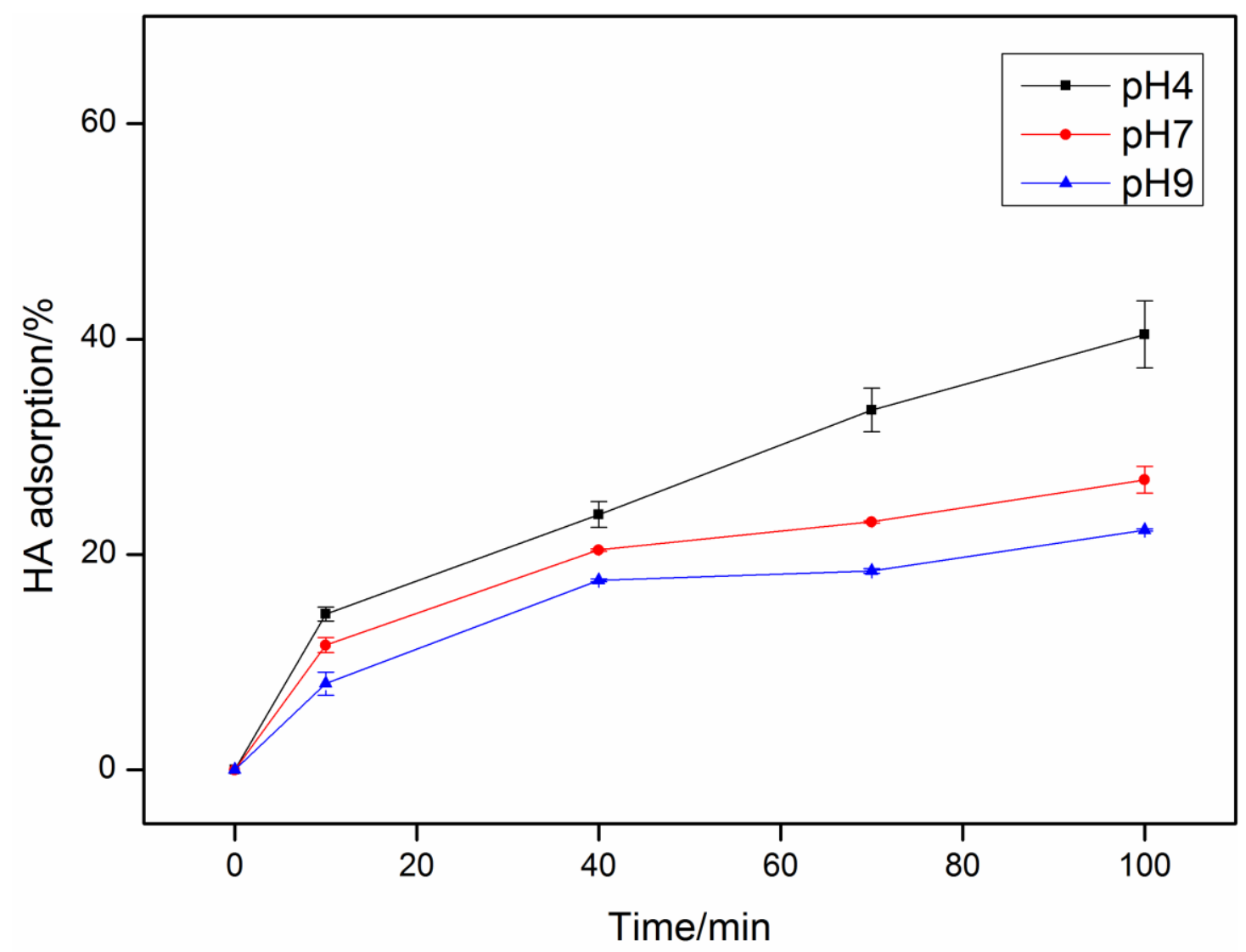

Figure 6. Adsorption of humic acid on montmorillonite/ $\mathrm{MnO}_{2}$ as a function of time at different pHs. Experimental conditions: initial humic acid and montmorillonite concentrations of $5 \mathrm{mg} \mathrm{C} \mathrm{L}^{-1}$ and $0.25 \mathrm{~g} \mathrm{~L}^{-1}$ respectively. Error bars are the standard deviations of triplicate analyses. 
3

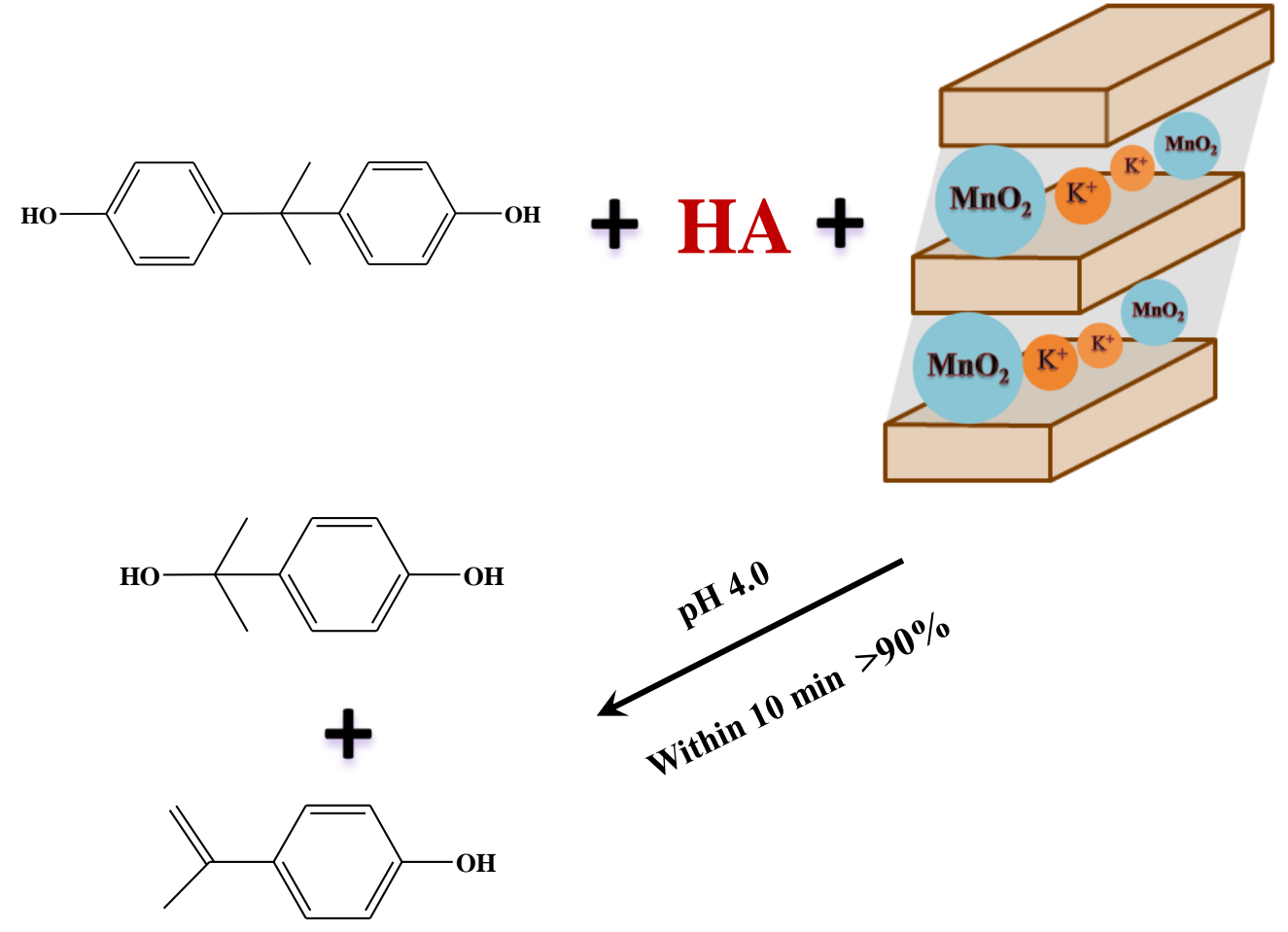

4

5 